\title{
Combustion of lignocellulosic materials in an experimental fluidized bed system
}

\author{
G. Lopez-Ocaña ${ }^{1}$, R. G. Bautista-Margulis ${ }^{1}$, \\ J. R. Hernandez-Barajas ${ }^{1}$, H. O. Rubio-Arias ${ }^{2}$ \\ \& R. A. Saucedo-Teran ${ }^{3}$ \\ ${ }^{1}$ Juarez Autonomous University of Tabasco, Mexico \\ ${ }^{2}$ College of Zootechnology, Autonomous University of Chihuahua, \\ Mexico \\ ${ }^{3}$ INIFAP, Mexico
}

\begin{abstract}
Incineration via fluidized bed combustion is a worldwide technology used for the thermal treatment of solid wastes with various calorific values. The objective of the present investigation was to evaluate the combustion efficiency and gas products from a three-phase combustor in order to thermally treat lignocellulosic materials obtained from urban solid wastes generated in Villahermosa-Tabasco, Mexico. The experiments were carried out in three sections: (EXP-1) the bed temperature $(\mathrm{Tb})$ was varied from 800 to $900^{\circ} \mathrm{C}$, having a static bed height $(H s)$ of $0.15 \mathrm{~m}$; (EXP-2); same $T b$ range but $H s=0.20 \mathrm{~m}$; (EXP-3) same $T b$ range but $H s=0.25 \mathrm{~m}$. Throughout the experiments, the combustor was operated with an average excess air $(X S A)$ of $168 \%$ and a mean bed particle size $(D p)$ of $0.8 \mathrm{~mm}$. The results revealed that the combustion efficiency varied from $73.6-82.6 \%$ for $H s=0.15 \mathrm{~m}, 78.4-87.9 \%$ for $H s=0.20 \mathrm{~m}$, and $80.1-90.6 \%$ for $H s=0.25 \mathrm{~m}$. At $\mathrm{Tb}<815^{\circ} \mathrm{C}$ and $H s=0.15 \mathrm{~m}$, low combustion efficiencies were obtained (73-80\%), with relatively high $\mathrm{CO}$ emissions $(280-310 \mathrm{ppm})$. At $\mathrm{Tb}>850^{\circ} \mathrm{C}$ and $H s=0.20-0.25 \mathrm{~m}$, higher combustion efficiencies were attained (82-91\%), with maximum emission concentrations of $\mathrm{CO}(102 \mathrm{ppm}), \mathrm{SO}_{2}(13 \mathrm{ppm})$ and $\mathrm{NO}_{\mathrm{x}}(17 \mathrm{ppm})$ that never exceeded the maximum permissible levels established in the current Mexican environmental legislation. The prototype probed to be technically and environmentally feasible for the treatment of lignocellulosic materials via fluidized bed combustion.
\end{abstract}

Keywords: combustion, lignocellulosic residues, fluidized bed. 


\section{Introduction}

The handling, treatment and final disposal of urban solid waste (USW) represents a great challenge for environmental authorities. Consequently, a series of control regulations have been created in order to improve the efficiency for handling and disposal of such wastes [1]. In the near future, traditional direct methods (e.g., landfill and underground injection) will be replaced by incineration, combined biological and physical-chemical treatment, chemical stabilization-solidification and others [2, 3]. To date, state of the art incineration systems have been demonstrated to achieve the highest levels of control and destruction of USW. In this context, incineration employs thermal decomposition via oxidation at high temperatures $\left(800-1100{ }^{\circ} \mathrm{C}\right)$ destroying the organic fraction of the residue and, therefore, reducing its volume. Nevertheless, the incinerators must comply with a given regulation for performance and operation, such as: high combustion efficiency, removal and destruction of toxic gases, permissible limits for particulate emission, semicontinuous monitoring in the process, a specific minimum temperature, and acceptable levels of residence time in the exhaust gases [4-6]. Likewise, various incineration technologies have been developed to deal with different types and physical forms of residues.

In the United States of America, a critical review identified 221 incinerators of hazardous and conventional wastes $[7,8]$ where the design of liquid injection, rotary kilns, fixed hearth and fluidized bed incinerators were highlighted. The fluidized bed combustors represent one of the most promising technologies for incinerating organic and plastic residues, contaminated sludge and biomass [3, 9-11]. Also, control of the combustion process has been selected as the main strategy for reducing emissions into the atmosphere. Furthermore, a strong correlation has been found between temperature, residence time and emission rate $[12,13]$.

During the operation of a fluidized bed incinerator at pilot plant scale, Saxena and Jotshi [14] reported $\mathrm{SO}_{\mathrm{x}}$ and NOx emissions ranging from 20 to 35 ppm and 100 to $139 \mathrm{ppm}$ respectively, having oxygen concentrations in the flue gases between 13.4 and $16.1 \%$. Swithenbank et al. [15] found an oxygen concentration of $16.9 \%$ in the flue gas of clinical wastes. Likewise, certain operating conditions minimized the $\mathrm{CO}$ formation and reduced the dioxin and furan emissions $[16,12]$. The $\mathrm{CO}$ forms due to incomplete combustion and, therefore, an excess air is required to attain the optimum oxidation of the fuel. Wiley [17] suggested a minimum oxygen concentration of $1-2 \%$ in the combustion products. The objective was to evaluate the combustion efficiency and gases products from a three-phase combustor in order to thermally treat lignocellulosic materials obtained from urban solid wastes generated in Villahermosa-Tabasco, Mexico. The experimental combustor was specifically designed and constructed to cope with the operating and fluidizing requirements in the current study. Also, the flue gas composition $(\mathrm{CO}, \mathrm{NO}$, $\mathrm{NO}_{\mathrm{x}}$ and $\mathrm{SO}_{2}$ ) was determined during the combustion process under various operating conditions. 


\section{Materials and methods}

\subsection{Characterization of USW}

The USW samples were taken according to the Mexican technical norm specifications [18]. The field work was performed at the open municipal waste site located outskirts Villahermosa city in Tabasco, Mexico. Indirect methods were employed to quantify the USW, the loading count and the truck number [19]. To determine the USW generation, the samples were applied for a period of eight days and analyzed in seven days. Nevertheless, the first day of USW sampling was excluded for not being representative. In this study six sectors were considered throughout the sampling: central downtown (S1), northeast (S2), southwest (S3), north-northeast (S4), east (S5) and peripherical area (S6). Samplings were carried out three times a week within each sector, allowing for a specific classification and quantification of the products and by-products.

\subsection{Design and operating characteristics of the experimental combustor}

The design specifications of the combustor can be seen in Figure 1.

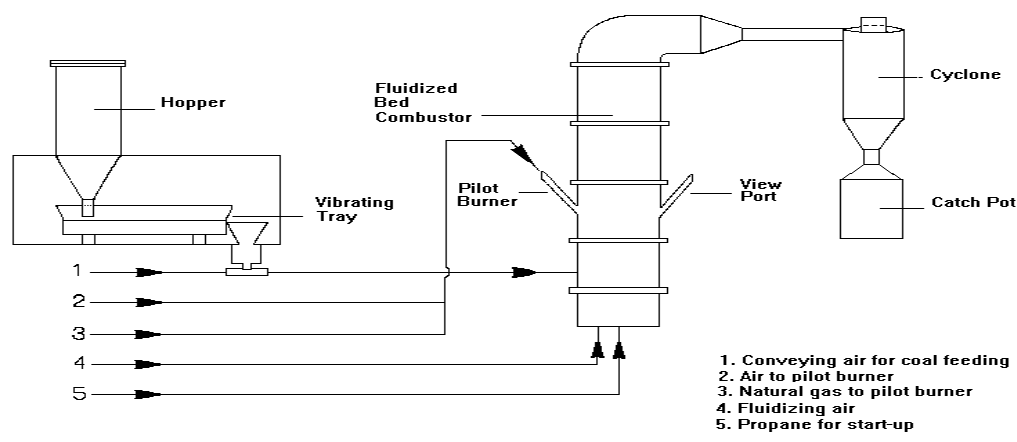

Figure 1: Scheme of the experimental fluidized-bed combustor used in the present study.

The combustor was made up of mild steel and constructed in three cylindrical sections with an internal diameter of $0.1 \mathrm{~m}$. The bed and plenum sections are $0.45 \mathrm{~m}$ and $0.25 \mathrm{~m}$ high, respectively; while the height (freeboard) of the two remaining sections is $0.50 \mathrm{~m}$ each. Two tubes in "V" shape were coupled to the combustor walls in a $45^{\circ}$ angle. Such adjacent tubes were employed, on the one hand, for the pilot burner and, on the other hand, as an observation port. To feed the USW, an open area was made in the bed section. The bed material was made up of silica sand with a mean particle size of $0.8 \mathrm{~mm}$. The plenum comprised the air and gas distributor and was constructed in stainless steel with a $0.1 \mathrm{~m}$ internal 
diameter and 0.01 thick. To distribute the air and gas inside the combustor, five standpipes were made of stainless steel with $9 \mathrm{~mm}$ diameter and $54 \mathrm{~mm}$ length. At the top of each standpipe, four orifices were perforated with $2 \mathrm{~mm}$ diameter.

The feeding of USW into the experimental prototype was performed manually and discontinuously, working as a batch reactor. The lignocellulosic material was triturated to get an average size of $5 \mathrm{~mm}$ diameter $[20,21]$. Thermocouples type " $K$ " was used to monitor the temperatures in the bed, the freeboard and the exit flue gas. The thermocouple material was stainless steel with a temperature interval between -129 to $1371{ }^{\circ} \mathrm{C}$, and $\pm 0.1 \%$ error. The temperature was recorded in a Pro TM 45 panel control (43/4 Digit Microprocessor Based Temperature/Process Indicator). The air for both the pilot burner and combustion system was supplied by a compressor with a capacity of $0.56 \mathrm{~m}^{3} / \mathrm{min}$ and $14 \mathrm{~kg} / \mathrm{cm}^{2}$ pressure. The temperature and concentration of the combustion products were measured with a portable analyzer TESTO $300 \mathrm{M \& XL}$.

The experiments were conducted in the fluidized bed combustor, under the following operating conditions: $1-3 \mathrm{~h}$ operating time; $66-90 \mathrm{~g} / \mathrm{min}$ mass flowrate; $800-900^{\circ} \mathrm{C}$ bed temperature; $0.35-1.06 \mathrm{~kg} / \mathrm{cm}^{2}$ air pressure; 12.4 $13.9 \%$ excess oxygen; $0.8 \mathrm{~mm}$ mean particle bed size and $5 \mathrm{~mm}$ average residue size. Three experimental runs were carried out five times each, as follows: (EXP1) the $T b$ was varied from 800 to $900^{\circ} \mathrm{C}$, having a $H_{s}=0.15 \mathrm{~m}$; (EXP-2) same $T b$ range but $H s=0.20 \mathrm{~m}$; (EXP-3) same $T b$ range but $H_{s}=0.25 \mathrm{~m}$.

\subsection{Combustion efficiency}

The combustion efficiency $(\eta)$ was determined by monitoring carbon monoxide (CO) and carbon dioxide $\left(\mathrm{CO}_{2}\right)$ in the exit flue gases. The $\mathrm{CO}$ and $\mathrm{CO}_{2}$ concentrations were measured with a portable combustion gas analyzer and used to calculate the combustion efficiency, as follows:

$$
\eta=100-\left[K_{n e t} \frac{\left(T_{g}-T_{a}\right)}{C_{\mathrm{CO}_{2}}}+\left(X \frac{\left(210+2.1 T_{g}-4.2 T_{a}\right)}{1000 Q_{g r}}\right)+\frac{k_{1} Q_{g r} C_{C O}}{Q_{n e t} C_{\mathrm{CO}_{2}}+C_{C O}}\right]
$$

where $T_{g}$ is the flue gas temperature, $T_{a}$ is the room temperature, $C_{\mathrm{CO} 2}$ is the $\mathrm{CO}_{2}$ concentration measured, $C_{C O}$ is the $\mathrm{CO}$ concentration measured, $K_{\text {net }}=0.390, K_{l}$ $=40, Q_{r}=53.42$ y $Q_{n e t}=48.16$. In addition, nitric oxide (NO), nitrogen oxides $\left(\mathrm{NO}_{\mathrm{x}}\right)$ and sulfur dioxide $\left(\mathrm{SO}_{2}\right)$ were measured in the exhaust gases. The combustion products were analyzed every $10-15 \mathrm{~min}$ period after reaching stable operating conditions, that is, $5 \mathrm{~min}$ of constant bed temperature. The desired bed temperature was obtained by adjusting the USW feeding flow.

\section{Results and discussion}

From the USW estimated in six sectors of Villahermosa city, sector S1 was shown to be the highest generation with 210 tons/day and average density of $230.3 \mathrm{~kg} / \mathrm{m}^{3}$. The other five sectors produced various quantities of volumetric 
weight and USW generation, as illustrated in Table 1. In average, the six sectors generated 740 tons/day throughout the sampling period. In some sectors, certain materials are recovered before its final disposal. In Mexico, this pre-selection of recycled material is known as "pepena". Because of this activity, the information shown in Table 1 does not represent the USW generation but the USW composition at site. Sector S5 was chosen to be the fuel supply for feeding the lignocellulosic material in the experimental fluidized-bed combustor. Such a sector represents approximately $12 \%$ of the total USW volume generated in the city and the "pepena" reduces the recyclable material (e.g., textiles, aluminum, cardboard, paper and cans). The following by-products were found in S5: rigid plastic $(12.7 \%)$, paper $(29 \%)$, polyethylene $(9.9 \%)$, organic matter $(30.3 \%)$, glass $(4.6 \%)$, fine residues $(1.7 \%)$, textiles $(1.0 \%)$ and aluminum $(9.9 \%)$. Likewise, Table 2 shows the elemental analysis for both the USW composition and the lignocellulosic material from S5.

Table 1: $\quad$ USW generation for each zone in Villahermosa, Mexico.

\begin{tabular}{|c|c|c|c|c|c|c|}
\hline & $\begin{array}{c}\text { Sector } \\
1\end{array}$ & $\begin{array}{l}\text { Sector } \\
2\end{array}$ & $\begin{array}{c}\text { Sector } \\
3\end{array}$ & $\begin{array}{c}\text { Sector } \\
4\end{array}$ & $\begin{array}{c}\text { Sector } \\
5\end{array}$ & $\begin{array}{c}\text { Sector } \\
6\end{array}$ \\
\hline $\begin{array}{l}\text { Volumetric weight } \\
\left(\mathrm{kg} / \mathrm{m}^{3}\right)\end{array}$ & 230.3 & 203.7 & 216.3 & 215.9 & 180.3 & 200.2 \\
\hline $\begin{array}{l}\text { Generation } \\
\text { (Tons/day) }\end{array}$ & 210.0 & 160.0 & 100.0 & 70.0 & 92.0 & 115.0 \\
\hline Subproducts & \multicolumn{6}{|c|}{ Percentage (\%) } \\
\hline Rigid plastic & 10.0 & 2.7 & 26.7 & 26.3 & 12.7 & 13.0 \\
\hline Paper & 17.3 & 5.9 & 15.8 & 7.0 & 29.0 & 11.2 \\
\hline Polyethylene & 15.5 & 9.7 & 12.7 & 11.9 & 9.9 & 8.9 \\
\hline Plastified cardboard & 7.7 & & & & & 6.3 \\
\hline Organic matter & 43.6 & 47.9 & 29.0 & 29.0 & 30.3 & 47.7 \\
\hline Glass & 3.2 & 10.3 & & & 4.6 & 0.9 \\
\hline Fine residues & 2.7 & 11.9 & & & 1.7 & 3.9 \\
\hline Textiles & & 2.9 & & & 1.0 & 2.3 \\
\hline Aluminum & & 2.2 & & & 9.9 & \\
\hline UNICEF & & 6.8 & & & 0.9 & \\
\hline Cardboard & & & 8.3 & 11.3 & & \\
\hline Cans & & & 7.5 & 14.4 & & 5.8 \\
\hline
\end{tabular}

For the EXP-1 (Figure 2), the combustion efficiency varied from 74 to $82 \%$ at bed temperatures ranging from 810 to $900^{\circ} \mathrm{C}$, respectively. In this experiment, the $\mathrm{CO}$ concentration diminished from 310 to $146 \mathrm{ppm}$ as the bed temperature increased from 810 to $900^{\circ} \mathrm{C}$. This behavior may be explained by the oxidation of $\mathrm{CO}$ to form $\mathrm{CO}_{2}$ at high temperatures, since the reaction velocity at $900^{\circ} \mathrm{C}$ is six times higher than that at $800^{\circ} \mathrm{C}[22]$. On the contrary, the $\mathrm{CO}_{2}, \mathrm{NO}$ and $\mathrm{NOx}$ values increased as the temperature was raised above $855^{\circ} \mathrm{C}$.

The increase in NO concentration was presumably due to the kinetic reaction of NO according to the extended Zeldovich mechanism, where the atomic oxygen reacts with the molecular nitrogen to form $\mathrm{NO}$ and atomic nitrogen [22]. Basically at $900^{\circ} \mathrm{C}$, the $\mathrm{NO}$ reaction velocity is 20 times higher than that at $800^{\circ}$ 
C, which favors its formation. Meanwhile, the $\mathrm{SO}_{2}$ concentration did not present a clear tendency. Also, it was observed that $\mathrm{SO}_{2}$ values from 2 to 5 ppm were attained for the highest bed temperature.

Table 2: $\quad$ Elemental composition of USW and lignocellulosic material.

\begin{tabular}{cccccccc}
\hline \multirow{2}{*}{ Sector } & \multicolumn{9}{c}{ Elemental composition (\% in weight) } & Ash & Moisture \\
& C & H & O & N & S & & \\
\hline 1 & 32.7 & 4.6 & 20.6 & 1.4 & 2.0 & 20.1 & 18.6 \\
2 & 41.5 & 5.9 & 30.0 & 3.4 & 0.3 & 5.2 & 13.7 \\
3 & 26.3 & 5.5 & 28.0 & 0.3 & 0.2 & 7.0 & 32.7 \\
4 & 34.4 & 4.3 & 32.2 & 1.8 & 0.5 & 4.0 & 22.8 \\
5 & 42.2 & 5.5 & 29.3 & 1.6 & 0.3 & 2.2 & 18.9 \\
6 & 34.2 & 5.0 & 30.6 & 0.4 & 2.3 & 3.6 & 23.9 \\
\hline
\end{tabular}

\begin{tabular}{cccccccc}
\hline & \multicolumn{9}{c}{ Elemental composition (\% in weight) } & & \\
Sector & & \multicolumn{2}{c}{ Lignocellulosic Material } & & Ash & Moisture \\
& $\mathbf{C}$ & $\mathbf{H}$ & $\mathbf{O}$ & $\mathbf{N}$ & $\mathbf{S}$ & & \\
\hline 5 & 41.04 & 5.87 & 40.02 & 0.23 & 0.02 & 9.41 & 3.41
\end{tabular}

Carbon (C), Hydrogen (H), Oxygen (O), Nitrogen (N), Sulfur (S). N.B. Oxygen was obtained by difference $[100 \%-\Sigma(\mathrm{C}+\mathrm{H}+\mathrm{N}+\mathrm{S})]$.

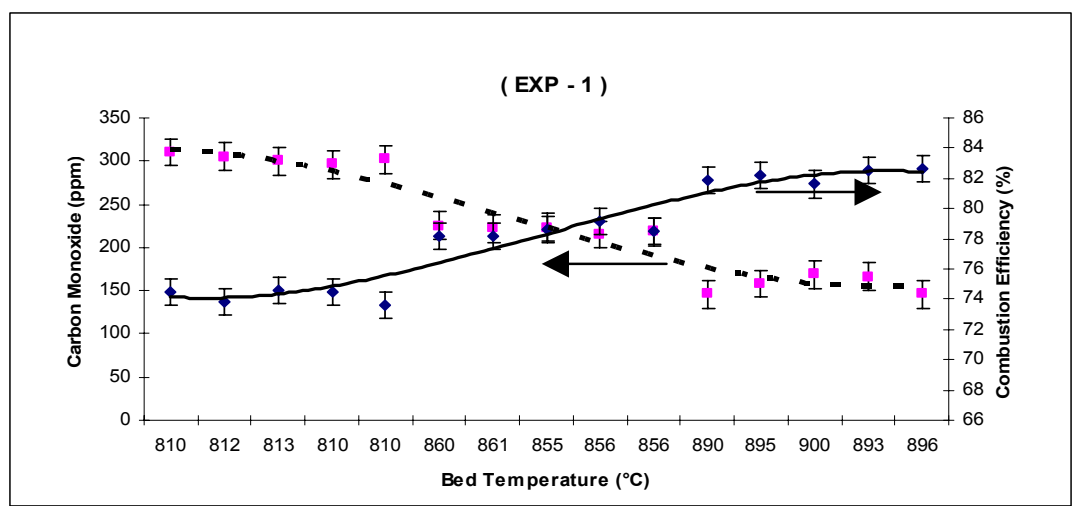

Figure 2: Combustion efficiency and $\mathrm{CO}$ concentration tendencies in EXP-1.

For the EXP-2 (Figure 3), the combustion efficiency was also increased when increasing the temperature of the fluidized bed combustor. The lower (78\%) and higher values $(87 \%)$ for combustion efficiency were obtained at 810 and $885^{\circ} \mathrm{C}$ bed temperature, respectively. The CO concentration decreased from 296 to 122 ppm. Likewise, Table 3 showed that $\mathrm{CO}_{2}, \mathrm{NO}$ and NOx values increased as the 
temperature was raised above $850^{\circ} \mathrm{C}$, however, the $\mathrm{SO}_{2}$ concentration was kept constant in the range of 3 and 6 ppm throughout de experiments.

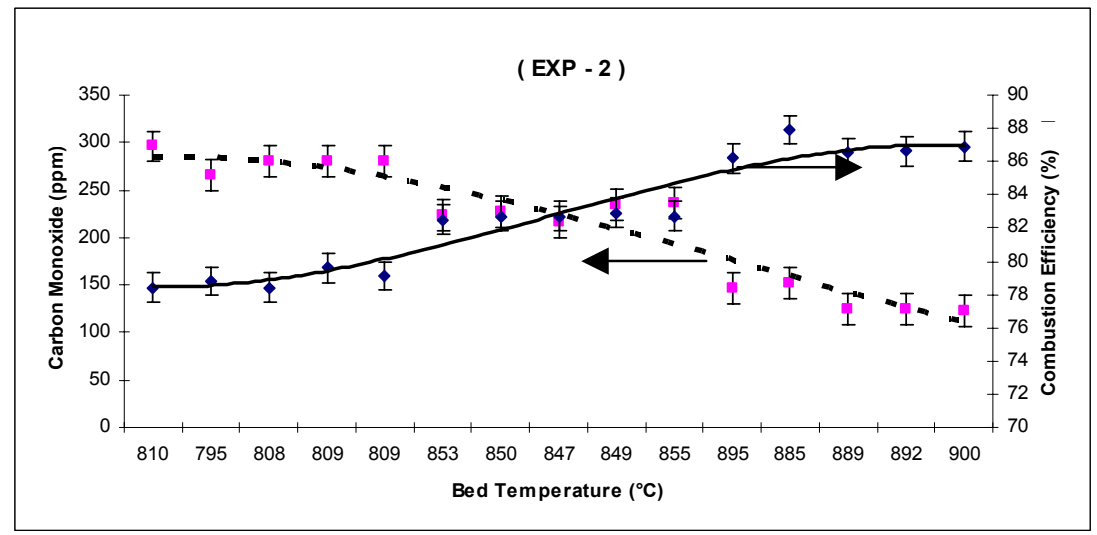

Figure 3: $\quad$ Combustion efficiency and $\mathrm{CO}$ concentration tendencies in EXP-2.

The results in EXP-3 showed a significant increase in combustion efficiency when increasing the temperature, having a decrease in $\mathrm{CO}$ concentration (Figure 4). Combustion efficiencies of 80 and $90 \%$ were determined at bed temperatures of 813 and $902^{\circ} \mathrm{C}$, respectively. Under such operating conditions, the values of $\mathrm{CO}$ concentration were $268 \mathrm{ppm}$ for the lowest temperature and $102 \mathrm{ppm}$ for the highest. Unlike EXP-1 and EXP-2, the $\mathrm{CO}_{2}, \mathrm{NO}, \mathrm{NOx}$ and $\mathrm{SO}_{2}$ concentrations behaved steadily in relation to the increase in bed temperature.

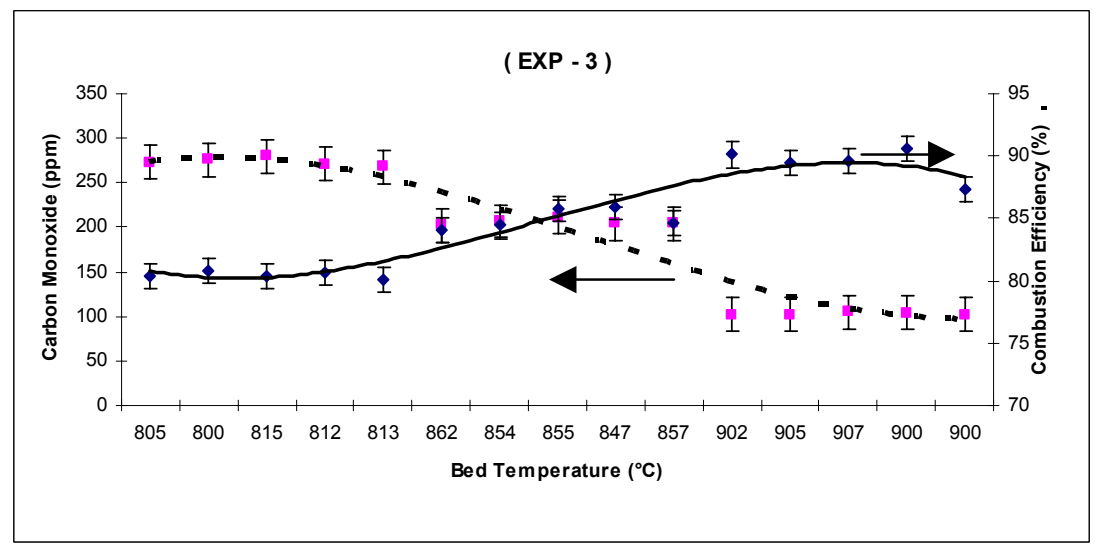

Figure 4: Combustion efficiency and CO concentration tendencies in EXP-3.

Although the current experimental combustor does not have any connection to other treatment system or gas recirculation by-pass, the combustion efficiencies achieved in the fluidized bed were relatively high (90\%) at high temperatures $\left(902^{\circ} \mathrm{C}\right)$. The $\mathrm{CO}, \mathrm{NO}, \mathrm{NOx}$ and $\mathrm{SO}_{2}$ concentrations were found to 
be below the maximum permissible levels established in the Mexican environmental legislation [18]. The proposed experimental prototype showed that high combustion efficiencies can be proportional to the increase in temperature within the fluidized bed combustor. In this case, the combustor could presumably reach higher efficiencies if heat losses to the surroundings were reduced and the excess air was appropriate [5].

In a fluidized-bed incinerator at pilot scale, Saxena and Jotshi [14] reported that oxygen concentrations in the flue gas should be ranging between 13.4 and $16.1 \%$; Swithenbank et al. [15] determined an optimum oxygen concentration of $16.9 \%$ during the incineration of clinical waste. Previous works on this field have also found that commercial incinerators were operated under similar excess oxygen conditions. In agreement with these investigations, the proposed fluidized bed combustor presented similar oxygen concentrations varying from 12.0 to $16.9 \%$ throughout the experiments. On the other hand, companies like Energy Incorporated Co (EIC) and Energy Products of Idaho (EPI) reported $\mathrm{CO}_{2}$ values in the flue gas in the range of 5.2 and $6.6 \%$ [17]. For the clinical waste incinerator, the $\mathrm{CO}_{2}$ discharges were found to be in $3.1 \%$ [15]. While in the current experimental combustor, the $\mathrm{CO}_{2}$ concentrations were measured between 1.2 y $5.6 \%$.

In this context, Saxena and Jotshi [14] reported SOx and NOx values in the range of 20-35 ppm and 100-139 ppm, respectively. The EIC and EPI prototypes showed SOx concentrations of $350 \mathrm{ppm}$ and NOx concentrations of $35 \mathrm{ppm}$. Likewise, Swithenbank et al. [15] found higher emission levels for NOx $\left(51 \mathrm{mg} / \mathrm{m}^{3}\right)$ than $\mathrm{SO}_{2}\left(17 \mathrm{mg} / \mathrm{m}^{3}\right)$ from the incineration of clinical residues. In the current experiments, the SOx and NOx concentrations never exceeded $40 \mathrm{ppm}$ in the exhaust gases under similar operating conditions $\left(900^{\circ} \mathrm{C}\right)$. Regarding the combustion efficiency, the experimental works mentioned above reported higher values (93-99\%) than those obtained in this investigation (80-90\%) since they combined the fluidization process with pyrolysis. These prototypes operated at temperatures between 850 and $950^{\circ} \mathrm{C}$ and excess air ranging from 35 to $60 \%$ (Table 3).

Table 3: Operability and flue gas composition from the current experimental prototype compared to others cited in the literature.

\begin{tabular}{lccccc}
\hline \multicolumn{1}{c}{ Parameters } & Saxena & EIC-EPI & GA Tech. & LIN & DACBIOL \\
\hline $\mathrm{O}_{2}(\%)$ & $13.4-16.1$ & 16.9 & 0 & 6 & $12.4-13.9$ \\
$\mathrm{CO}_{2}(\%)$ & $5.2-6.6$ & $5.2-6.6$ & & & $3.2-4.9$ \\
$\mathrm{NO}_{\mathrm{x}}(\mathrm{ppm})$ & $100-139$ & 35 & & $<100$ & $<40$ \\
$\mathrm{SO}_{\mathrm{x}}(\mathrm{ppm})$ & $20-35$ & 350 & & $<100$ & $<40$ \\
$\mathrm{CO}(\mathrm{ppm})$ & 30 & 0 & 100 & & $102-310$ \\
Combustion efficiency $(\%)$ & 99 & 93 & 99.9 & 96 & $73-90$ \\
Operating Temperature $\left({ }^{\circ} \mathrm{C}\right)$ & 800 & $750-800$ & 1100 & $800-940$ & $800-900$ \\
\hline
\end{tabular}

GA Tech, prototype designed by GA Tech. Inc. Company (Rickman et al., [24]). EIC-EPI, prototype developed by Energy Incorporated Company (EIC). Saxena, prototype developed by Saxena and Jotshi [14]. LIN, prototype developed by Lin et al. [23]. DACBIOL, prototype was developed by the corresponding author. 


\section{Conclusions}

The experimental prototype demonstrated to be technically and environmentally feasible for the thermal treatment of lignocellulosic materials via fluidized bed combustion. The highest combustion efficiency $(90 \%)$ was obtained at $902^{\circ} \mathrm{C}$ bed temperature and $13.9 \%$ excess oxygen. The experimental results suggest that higher combustion efficiencies may be achieved if: 1) the USW mixtures are homogenized, 2) a continuous feeding system is used and 3) the combustor is well insulated as to avoid important energy losses to the surroundings. Also, the $\mathrm{SO}_{2}$ and $\mathrm{NO}_{\mathrm{x}}$ emissions did not exceed the maximum permissible levels established by the Mexican environmental legislation. It is recommended to run more experiments in order to better understand the heterogeneous combustion fundamentals of USW as well as its solid and gaseous emissions, under various fluidizing and operating conditions. Likewise, a number of studies will be required to understand the combustion behavior of both USW and lignocellulosic materials at different bed particle sizes.

\section{References}

[1] SEMARNAT (2002) Dirección general de manejo integral de contaminantes. Página web, http://www.semarnat.gob.mx. Correo: dgmic@ semarnat.gob.mx

[2] Scala F, Salatino P (2001) Modeling fluidized bed combustion of highvolatile solid fuels. Chemical Engineering Science. 57: 1175-1196

[3] Lin W, Johansen KD, Frandsen F (2003) Agglomeration in bio fuel fired fluidized bed combustors. Chemical Engineering Journal. 96: 171-185.

[4] Oxley JH (1995) Combustion in fluidized beds. $1^{\text {st }}$ International colloquium on pollution control and diagnosis. Instituto de Investigaciones Electricas. Cuernavaca, Morelos, Mexico. 10-12 July 1995. pp 1-24

[5] Kaynak B. Topal H. Atimtaya AT (2005) Peach and apricot stone combustion in a bubbling fluidized bed. Fuel Processing 86: 1175-1193

[6] Lin CL, Wey MY, Yu WJ (2005) Emission characteristics of organic and heavy metal pollutants in fluidized bed incineration during the agglomeration/defluidization process. Combustion and Flame. 143: 139149.

[7] Oppelt ET (1986) Performance Assessment of Incinerators and High Temperature Industrial Processes Disposing Hazardous Waste in the U.S., in Hazardous and Industrial Solid Waste Testing and Disposal, ASTM Standard Publication 933.

[8] Kisuk CPE (1998) Solid waste incineration. U.S. Corps. of Engineers, Engineering Division, Report T1 814-21, Washington D.C.

[9] Hristov JY (2002) Fluidized Bed Combustion as a Risk-Related Technology: a Scope of Some Potential Problems. IFRF Combustion Journal. Article No. 200208, ISSN 1562-479X, 1-34 pp.

[10] Fang M, Yang L., Chen G, Shi Z. Luo Z, Cen K (2004) Experimental study on rice husk combustion in a circulating fluidized bed. Fuel Processing Technology. 85: 1273-1282. 
[11] Yan R Liang DT, Tsen L (2005) Case studies-problem solving in fluidized bed waste fuel incineration. Energy Conversion \& Management. 46: 11651178

[12] Wang W (1993) Emission control hardware cost in California. Report 80144, Ontario Hydro, Toronto, Canada

[13] Johansson K, Norling R, Hjornhede A, Almstedt AE, Jonson F, Nylund A (2004) Hydrodynamics and steel tube wastage in a fluidized bed at elevated temperature. Chemical Engineering Science. 59: 31-40

[14] Saxena SC, Jotshi CK (1994) Fluidized-Bed incineration of waste materials. Prog. Energy Combust. Sel. 20: 281-324

[15] Swithenbank J, Nasserzadh V, Ewan and Delay BCR, Lawrence D, Jones B (1997) Research investigations at the municipal and clinical waste incinerators in Sheffield, UK. Environmental Progress. 16(1): 65-81

[16] Hasfelriis F (1987) Optimization of Combustion Conditions to Minimize Dioxin, Furan and Combustion Gas Data from Tests Programs at Three MSW Incinerators. Journal APCA 37(12), 1451 p

[17] Wiley SK (1987). "Incinerate-bed your hazardous waste". Hydrocarbon Processing. Tulsa, Oklahoma

[18] Norma Oficial Mexicana NOM-098-SEMARNAT-2002, Protección ambiental-incineración de residuos, especificaciones de operación y límites de emisión de contaminantes

[19] Tchobanoglous G, Theisein H, Vigil SA (1994) Gestión Integral de Residuos Sólidos. Ed. McGraw-Hill. México, D.F

[20] Díaz-Dagdug JJ (1999) Rediseño de un equipo triturador de bolsas de polietileno por medio del uso del escalamiento. Tesis, Instituto Tecnológico de Villahermosa, México

[21] Rodríguez AJ (2002) Planta de Bolsas de Polietileno (opción para mejorar el ambiente). Tesis de Ingeniería Química, Instituto Tecnológico de Villahermosa, Tabasco

[22] Borman GL, Ragland KW (1988) Combustion engineering. The McGrawHill Companies. USA. 613 pp

[23] Lin CH, Teng JT, Chyamg CS (1997) Evaluation of combustion efficiency and emission of pollutants by coal particles in a vortexing fluidized bed. Combustion and Flame. 110:163-172

[24] Rickman WS, Holder DT, Young DT (1985) Circulating Bed Incineration of Hazardous Wastes, Chemical Engineering Progress 81:34 